Syntax Literate: Jurnal Ilmiah Indonesia p-ISSN: 2541-0849

e-ISSN : 2548-1398

Vol. 6, No. 10, Oktober 2021

\title{
UJI FORMULASI DAN KEMASAN SERBUK INSTAN PERASAN KULIT BUAH JERUK NIPIS (CITRUS AURANTIFOLIA)
}

\author{
Ahmad Azrul Zuniarto, O Ahmad Mundzir, Nur Afifah Maulida \\ Program Studi Farmasi Sekolah Tinggi Farmasi (STF) YPIB Cirebon, Jawa Barat, \\ Indonesia \\ Email: aazuniarto@gmail.com, akhmundzir@gmail.com, afimaulida@gmail.com
}

\begin{abstract}
Abstrak
Penelitian ini bertujuan untuk mengetahui perasan kulit buah jeruk nipis (Citrus aurantifolia) dapat dijadikan serbuk instan, untuk mengetahui formulasi serbuk instan perasan kulit buah jeruk nipis (Citrus aurantifolia) memenuhi evaluasi sediaan, untuk mengetahui formulasi serbuk instan perasan kulit buah jeruk nipis (Citrus aurantifolia) memenuhi stabilitas sediaan dan untuk mengetahui jenis kemasan serbuk instan perasan kulit buah jeruk nipis (Citrus aurantifolia) yang disukai oleh panelis. Metode yang digunakan dalam penelitian serbuk instan perasan kulit buah jeruk nipis (Citrus aurantifolia) adalah metode foam mat drying dengan penambahan maltodekstrin konsentrasi 20\%, 25\% dan 30\%. Evaluasi sediaan serbuk instan perasan kulit buah jeruk nipis (Citrus aurantifoliai) yang dilakukan meliputi pemeriksaan kadar air, pemeriksaan kadar abu, uji waktu larut, uji waktu alir dan serbuk diam, uji organoleptis dan uji hedonik serbuk. Pada uji stabilitas menggunakan metode uji dipercepat suhu $0^{\circ}, 25^{\circ}$ dan $40^{\circ}$ selama 1 bulan. Uji hedonik kemasan dilakukan pada dua jenis kemasan berbeda yaitu kemasan alumunium foil dan plastik klip. Hasil evaluasi dan stabilitas serbuk instan perasan kulit buah jeruk nipis (Citrus aurantifolia) memenuhi persyaratan sediaan serbuk, untuk skor tertinggi uji hedonik serbuk yang diberikan oleh panelis yaitu terdapat pada formula 1 dengan penambahan konsentrasi maltodekstrin 20\%. Sedangkan jenis kemasan yang disukai oleh panelis adalah kemasan alumunium foil.
\end{abstract}

Kata Kunci: serbuk instan; perasan kulit buah jeruk nipis; kemasan

\section{Abstract}

This study aims to determine the juice of lime rind (Citrus aurantifolia) can be used as instant powder, to determine the instant powder formulation of lime peel juice (Citrus aurantifolia) fulfills the evaluation of the preparation, to determine the instant powder formulation of lime peel juice (Citrus aurantifolia). ) fulfills the stability of the preparation and to determine the type of instant powder packaging for lime peel juice (Citrus aurantifolia) preferred by the panelists. The method used in the research of instant powder for lime peel juice (Citrus aurantifolia) was a foam mat drying method with the addition of 20\%, 25\% and 30\% maltodextrin concentrations. Evaluation of the instant powder preparation of lime peel juice (Citrus aurantifoliai) which was carried out included checking the moisture content, checking the ash content, dissolving time test, flow time test and still

$\begin{array}{ll}\text { How to cite: } & \text { Zuniarto. A.A., O Ahmad Mundzir \& Nur Afifah Maulida (2021) Uji Formulasi Dan Kemasan Serbuk } \\ & \text { Instan Perasan Kulit Buah Jeruk Nipis (Citrus Aurantifolia). Syntax Literate: Jurnal Ilmiah Indonesia, } \\ & \text { 6(10). http://dx.doi.org/10.36418/ Syntax-Literate.v6i10.4346 } \\ & \\ \text { E-ISSN: } & \text { 2548-1398 } \\ \text { Published by: } & \text { Ridwan Institute }\end{array}$


powder, organoleptic test and powder hedonic test. In the stability test using the accelerated test method temperature of $0^{\circ}, 25^{\circ}$ and $40^{\circ}$ for 1 month. The packaging hedonic test was carried out on two different types of packaging, namely aluminum foil packaging and plastic clips. The results of the evaluation and stability of instant powder for lime peel juice (Citrus aurantifolia) met the requirements for powder preparation, for the highest score of powder hedonic test given by the panelists, namely formula 1 with the addition of $20 \%$ maltodextrin concentration Meanwhile, the type of packaging favored by the panelists is aluminum foil packaging.

Keywords: instant powder; lime peel juice; packaging

Received: 2021-09-20; Accepted: 2021-10-05; Published: 2021-10-20

\section{Pendahuluan}

Indonesia terkenal sebagai negeri yangsubur dan makmur. Tanaman yang ditanam di wilayah Indonesia akan tumbuh dengan baik. Itulah keunggulan wilayah Indonesia. Jika keunggulan tersebut mampu dimanfaatkan masyarakat dengan didukung penguasaan pengetahuan dan teknologi untuk mengembangkan budi daya tanaman, masyarakat akan sejahtera. Salah satu tanaman yangdapat dikembangkan di Indonesia adalah jeruk nipis (Budi, 2017). Jeruk nipis termasuk jenis tumbuhan perdu yang memiliki banyak dahan dan ranting. Batang pohonnya berkayu, ulet dan keras. Sedangkan permukaan kulit luarnya berwarna hijau tua dan kusam (Mpapa, 2019). Jeruk nipis mengandung senyawa flavonoid, seperti flavanon, limonoid, hesperidin, rhoifolin, dan naringin. Limonone berkhasiat sebagai ekspektoran, sedatif, dan aromatik (Budiana, 2013).

Minuman serbuk instan merupakan olahan pangan yang berbentuk serbuk, mudah larut dalam air, praktis dalam penyajian dan memiliki daya simpan yang lama karena kadar airnya yang rendah. Minuman instan dihasilkan dengan cara pengeringan prinsipnya adalah dehidrasi dalam proses tersebut umumnya diperlukan bahan pengisi sebagai komponen komponen bahan yang rusak saat pengeringan (Kumalaningsih, 2014).

Salah satu upaya yang dapat dilakukan untuk mengurangi masuknya uap air ke dalam produk yaitu dengan penggunaan kemasan. Pengemasan merupakan salah satu cara untuk melindungi atau mengawetkan produk pangan maupun non-pangan. Kemasan adalah suatu wadah atau tempat yang digunakan untuk mengemas suatu produk yang dilengkapi dengan label atau keterangan - keterangan termasuk beberapa manfaat dari isi kemasan. Pengemasan mempunyai peranan dan fungsi yang penting dalam menunjang distribusi produk terutama yang mudah mengalami kerusakan (Rahmawati, 2013).

Berdasarkan latar belakang diatas, maka peneliti tertarik untuk melakukan penelitian tentang pembuatan serbuk instan perasan kulit buah jeruk nipis dengan judul "Uji Formulasi dan kemasan Serbuk Instan Perasan Kulit Buah Jeruk Nipis (Citrus aurantifolia). Tujuan dilakukan penelitian tersebut yaitu untuk mengetahui perasan kulit 
buah jeruk nipis (Citrus aurantifolia) yang dapat dijadikan serbuk instan, untuk mengetahui formulasi serbuk instan perasan kulit buah jeruk nipis (Citrus aurantifolia) yang dapat memenuhi evaluasi sediaan, untuk mengetahui formulasi serbuk instan perasan kulit buah jeruk nipis (Citrus aurantifolia) yang dapat memenuhi stabilitas sediaan, dan untuk mengetahui jenis kemasan serbuk instan perasan kulit buah jeruk nipis (Citrus aurantifolia) yang disukai oleh panelis. Adapun manfaatnya yaitu diharapkan dapat memberi informasi dan pengetahuan bagi masyarakat dalam memanfaatkan perasan kulit buah jeruk nipis (Citrus aurantifolia).

\section{Metode Penelitian}

Metode penelitian dalam uji formulasi dan kemasan serbuk instan perasan kulit buah jeruk nipis (Citrusaurantifolia) menggunakan studi penelitian eksperimen yang dilakukan di laboratorium. Sampel pada penelitian ini adalah kulit buah jeruk nipis (Citrus aurantifolia). Dalam penelitian ini yang berperan sebagai variabel bebas adalah formulasi serbuk instan perasan kulit buah jeruk nipis (Citrus aurantifolia) dengan penggunaan maltodekstrin konsentrasi 20\%, 25\%, dan 30\%. Variabel terikat pada penelitian ini adalah pemeriksaan kadar air, pemeriksaan kadar abu, uji waktu larut, uji waktu alir serbuk dan sudut diam, uji organoleptis, dan uji hedonik.

1. Alat dan Bahan

Alumunium Foil, batang pengaduk, beaker glass, blender, cawan porselen, corong, gelas ukur, moisture balance, kaki tiga dan kassa asbes, kain saring, kemasan aluminium foil, Loyang, mixer, mortir dan stamper, oven, pengayak, spatel, spirtus, stopwatch, tanur listrik, Kulit buah jeruk nipis, aquadest, maltodekstrin, tween 80, CMC, asam sitrat, sukrosa, HCL pekat, serbuk magnesium, amil alcohol, pereaksi dragendroff, pereaksi mayer.

Determinasi tanaman dilakukan dengan menyamakan sifat morfologi tumbuhan, diantaranya yaitu bentuk, ukuran, jumlah bagian - bagian bunga, buah, dan lain - lain. Determinasi tanaman jeruk nipis (Citrus aurantifolia) dilakukan di laboratorium Sekolah Tinggi Farmasi YPIB Cirebon.

Pembuatan perasan diawali dengan cara mengumpulkan dan membersihkan 800 gram buah jeruk nipis (Citrus aurantifolia), kemudian bagian kulit buah jeruk nipis (Citrus aurantifolia) dikupas dan didapatkan sebanyak 350 gram, selanjutnya kulit buah jeruk nipis (Citrus aurantifolia) diblender dengan penambahan air sebanyak $175 \mathrm{ml}$ atau setara dengan perbandingan 2:1 selama 10 menit sampai menghasilkan perasan kulit

a. Uji Flavonoid

Ditimbang 1 gram perasan kulit buah jeruk nipis (Citrus aurantifolia), menambahkan 0,1 gram serbuk $\mathrm{Mg}$, selanjutnya menambahkan $1 \mathrm{ml} \mathrm{HCl}$ pekat, menambahkan $1 \mathrm{ml}$ amil alkohol., larutan dikocok secara perlahan dan dibiarkan memisah. Jika terjadi warna kuning, merah atau jingga pada lapisan amil alkohol maka terdapat flavonoid (Kristanti, 2008).

b. Uji Alkaloid 
Menyiapkan $2 \mathrm{ml}$ perasan kulit buah jeruk nipis (Citrus aurantifolia) diuapkan diatas cawan porselen, dilarutkan dengan $5 \mathrm{ml} \mathrm{HCl} 2 \mathrm{~N}$, larutan dibagi dalam 2 tabung reaksi, tabung I ditambahkan 3 tetes pereaksi dragendroff sedangkan tabung II ditambahkan 3 tetes pereaksi mayer, terbentuk endapan jingga pada tabung I dan endapan kuning pada tabung II menunjukkan adanya alkaloid (Farnsworth, 1996).

c. Uji Saponin

Sebanyak $1 \mathrm{ml}$ ekstrak dimasukkan ke dalam tabung reaksi, ditambahkan $10 \mathrm{ml}$ air panas, didinginkan Dan kemudian dikocok kuat-kuat selama 10 detik, terbentuk buih selama tidak kurang 10 menit, setinggi I cm sampai $10 \mathrm{~cm}$. Pada penambahan I tetes asam klorida $2 \mathrm{~N}$ buih tidak hilang (Kumoro, 2015).

Perasan kulit jeruk nipis dicampurkan dengan CMC sebanyak 1\% dan larutan tween 80 sebanyak 1\%. Setelah itu dilakukan proses pengocokan menggunakan mixer selama 5 menit. Selama proses pengocokan bahan, secara berturut - turut ditambahkan maltodekstrin sebanyak 20\%, 25\%, dan 30\% dan asam sitrat sebanyak $2 \%$, kemudian bahan dipindahkan dalam loyang yang telah dilapisi alumunium foil dan dilakukan pemanasan dalam oven dengan suhu 5080oC selama 3-5 jam. Hasil dari pengeringan kemudian digerus menggunakan mortir dan stamper sehingga dihasilkan serbuk kulit buah jeruk nipis. Proses pengeringan ditambahkan sukrosa dihomogenkan dan diayak menggunakan ayakan 100 mesh (Aliyah, 2019).

Tabel 1

Penimbangan Bahan Serbuk Instan Perasan Kulit Buah Jeruk Nipis (Citrus aurantifolia)

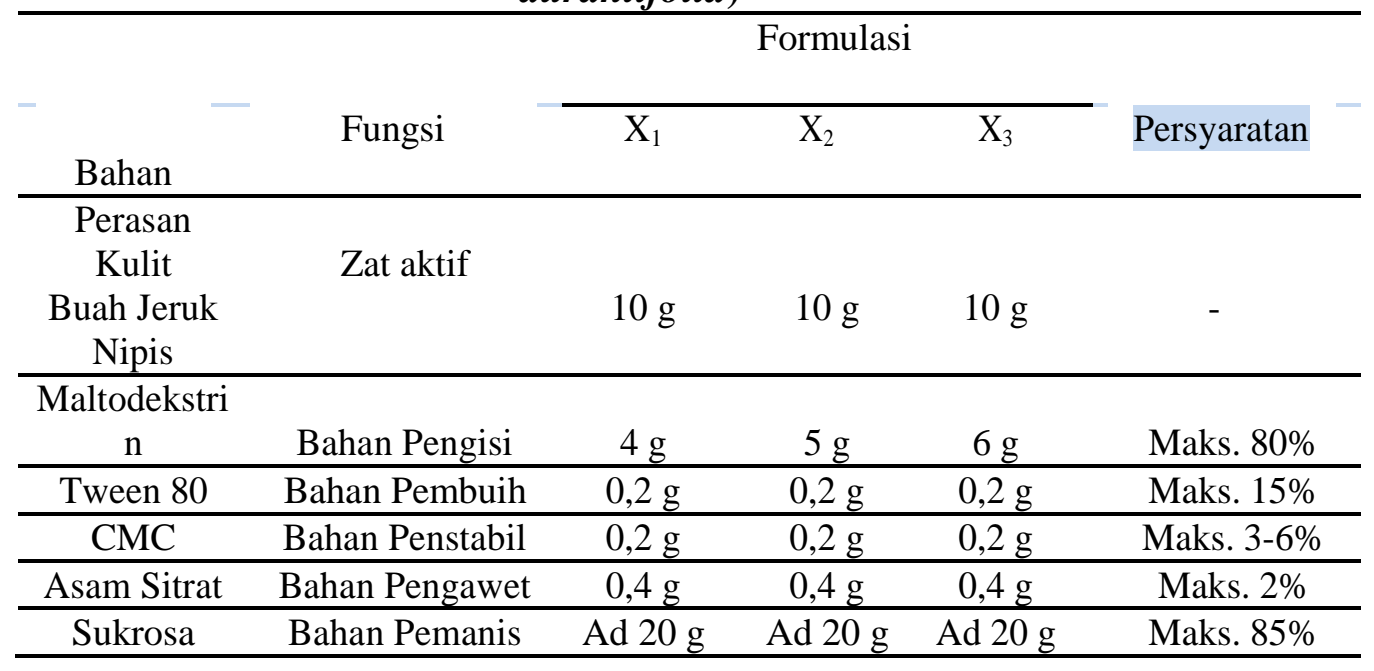

a. Uji Kadar Air

Menimbang sampel sebanyak 5 gram,kemudian sampel dimasukan dan diratakan kedalam moisture balance suhu 600C, dilakukakan pengulangan sampai memperoleh berat yang tetap. Hitung kadar air dengan rumus : 


\section{b. Uji Kadar Abu}

Menimbang sampel sebanyak 2 gram, sampel dimasukkan ke dalam cawan porselen, sampel dipanaskan beserta cawan di atas kassa asbes dan spirtus sampai asap hilang dan sampel memutih, cawan porselen diabukan didalam tanur listrik pada suhu 6000C sampai pengabuan sempurna, setelah itu cawan porselen didinginkan, kemudian menimbang berat cawan porselen tadi dan hitung kadar abu dengan menggunakan rumus :

Keterangan :

a : Berat cawan kosong (gram)

b : Berat cawan dengan sampel sebelum diabukan (gram)

c : Berat cawan dengan sampel setelah diabukan (gram) (Sudarmadji dan Suhardi, 1984)

c. Uji Waktu Larut

Menimbang 5 g sampel kemudian larutkan dalam $100 \mathrm{ml}$ air, kemudian menghitung kecepatan larut serbuk dengan menggunakan stopwatch dan dicatat berapa lama waktu sampai sampel benar-benar terlarut penuh dalam air (Antari, Chabaa, Iqdour, Zeroual, \& Safi, 2011).

d. Uji Waktu Alir dan Sudut Diam Menimbang 20 gram sampel

Masukkan ke dalam corong yang lubang bawahnya ditutup, dilakukan buka tutup bawah lalu amati waktu yang diperlukan sampai sampel mengalir semuanya, percobaan dilakukan tanpa dan dengan menggunakan alat penggetar, kemudian timbunan sampel dapat digunakan untuk menghitung sudut diam serbuk, lalu diukur diameter onggokan atau timbunan atau gunungan serbuk dengan menentukan 4 garis diameter, setelah itu mengambil harga rata - ratanya dan mengukur tinggi puncak timbunan serbuk dengan rumus sebagai berikut :

e. Uji Organoleptik

Uji organoleptik pada penelitian ini dilakukan menggunakan metode hedonik meliputi warna, aroma, dan rasa dari minuman serbuk instan kulit buah jeruk nipis (Citrus aurantifolia).

f. Uji Hedonik Serbuk

Uji Hedonik serbuk dilakukan dengan 10 panelis memberikan penilaian terhadap sediaan serbuk instan perasan kulit buah jeruk nipis (Citrus aurantifolia) menggunakan skala likert (1-5).

g. Uji Stabilitas

Uji stabilitas yang digunakan adalah dengan metode dipercepat, pengujian dilakukan setiap tujuh hari yaitu pada hari ke-0, 7, 14, 21 dan 28 dengan suhu $0 \square \mathrm{C}, 25 \square \mathrm{C}$ dan $40 \square \mathrm{C}$. Setelah itu diamati ada atau tidaknya perubahan yang terjadi pada masing-masing sediaan.

h. Uji Hedonik Kemasan

Uji Hedonik kemasan dilakukan dengan 10 panelis memberikan penilaian terhadap dua jenis kemasan serbuk instan perasan kulit buah jeruk nipis (Citrus 
aurantifolia) yaitu kemasan alumunium foil dan plastic klip menggunakan skala likert (1-5).

\section{Hasil dan Pembahasan}

A. Hasil Determinasi Tanaman

Hasil determinasi menunjukan bahwa tanaman yang digunakan adalah benar tanaman jeruk nipis (Citrus aurantifolia) dan merupakan tanaman famili Rutaceae (jenis jeruk-jerukan). Determinasi dilakukan di Laboratorium Sekolah Tinggi Farmasi YPIB Cirebon.

B. Hasil Pengumpulan Bahan

Kulit buah jeruk nipis yang digunakan adalah kulit buah jeruk nipis yang masih segar berwarna hijau. Kulit buah jeruk nipis ini diperoleh dari Desa Wangkelang Kecamatan Lemahabang Kabupaten Cirebon dan bahan lainnya diperoleh dari Laboratorium Teknologi Farmasi Sekolah Tinggi Farmasi YPIB Cirebon.

C. Hasil Pembuatan Perasan Kulit

Buah Jeruk Nipis (Citrusaurantifolia) Didapatkan perasan kulit buah jeruk nipis sebanyak $330 \mathrm{ml}$

1. Hasil Skrining Fitokimia

Tabel 2

Hasil Skrining Fitokimia

\begin{tabular}{ccc}
\hline Uji & Pereaksi & Hasil \\
\hline Fitokimia & Pelarut & \\
\hline Flavonoid & Serbuk $\mathrm{Mg}+$ & Warna \\
\hline & $\mathrm{HCl} \mathrm{pekat}+$ & kuning \\
\hline & Amil alcohol & $(+)$ \\
\hline Alkaloid & Dragendroff & Endapan \\
\hline & & jingga(+) \\
\hline & Mayer & Endapan \\
\hline & & kuning \\
\hline Saponin & & $(+)$ \\
\hline & Aquadest & Warna \\
\hline & & kuning(-) \\
\hline
\end{tabular}

D. Hasil Pembuatan Serbuk Instan

Perasan Kulit Buah Jeruk Nipis (Citrus aurantifolia) Untuk satu kemasan serbuk instan perasan kulit buah jeruk nipis (Citrus aurantifolia) dibutuhkan perasan kulit buah jeruk nipis sebanyak 10 gram, kemudian dilakukan pencampuran bahan bahan menggunakan mixer, bahan - bahan tersebut terdiri dari CMC dan tween 80 , ditunggu sampai berbuih. Kemudian ditambahkan maltodekstin dan asam sitrat. Setelah itu dikocok selama 5 menit sampai bahan - bahan tercampur membentuk foam. Selanjutnya, hasil yang sudah tercampur dipindahkan kedalam alumunium foil dan dimasukkan kedalam oven suhu $80^{\circ} \mathrm{C}$ selama $3-4$ jam. Setelah kering, bobot hasil pengeringan ditimbang. Kemudian, masing - masing hasil pengeringan 
ditambahkan sukrosa ad 20 gram. Hasil pengeringan dan sukrosa digerus menggunakan mortir dan stamper dan dilakukan pengayakan menggunakan ayakan 100. Total serbuk instan perasan kulit buah jeruk nipis (Citrus aurantifolia) adalah 180 gram untuk 9 kemasan. Dimana dalam 1 kemasan berisikan bobot serbuk sebanyak 20 gram.

1. Hasil Uji Kadar Air

Tabel 3

Hasil Uji Kadar Air

\begin{tabular}{cccc}
\hline Formula & Berat & Berat & Kadar \\
\hline & Awal & Akhir & Air $(\%)$ \\
\hline & $(\mathrm{g})$ & $(\mathrm{g})$ & \\
\hline $\mathrm{X} 1$ & $5 \mathrm{~g}$ & $4,951 \mathrm{~g}$ & $0,989 \%$ \\
\hline $\mathrm{X} 2$ & $5 \mathrm{~g}$ & $4,945 \mathrm{~g}$ & $1,11 \%$ \\
\hline $\mathrm{X} 3$ & $5 \mathrm{~g}$ & $4,948 \mathrm{~g}$ & $1,05 \%$ \\
\hline
\end{tabular}

Kadar air pada serbuk instan perasan kulit buah jeruk nipis (Citrus aurantifolia) untuk ketiga formula telah memenuhi SNI-01-4320-1996 yakni kadar air yang ada pada serbuk instan maksimal 3\%.

2. Hasil Uji Kadar Abu

\section{Tabel 4}

Hasil Uji Kadar Abu

\begin{tabular}{ccccc}
\hline Formula & $\mathrm{a}$ & $\mathrm{b}$ & $\mathrm{c}$ & Kadar \\
\cline { 1 - 4 } & & & & $\mathrm{abu}$ \\
\cline { 3 - 5 } & $(\mathrm{g})$ & $(\mathrm{g})$ & $(\mathrm{g})$ & $(\%)$ \\
\hline $\mathrm{X} 1$ & 69,04 & 71,04 & 69,05 & $0,5 \%$ \\
\hline $\mathrm{g} 2$ & $\mathrm{~g}$ & $\mathrm{~g}$ & $\mathrm{~g}$ & \\
\hline & 68,22 & 70,22 & 68,23 & $0,5 \%$ \\
\hline $\mathrm{X} 3$ & $\mathrm{~g}$ & $\mathrm{~g}$ & $\mathrm{~g}$ & \\
\hline & 72,57 & 74,57 & 72,59 & $1 \%$ \\
\hline
\end{tabular}

Pada ketiga formula memiliki kandungan mineral, kemurnian serta kebersihan yang baik karena konsentrasi maltodekstrin yang dihasilkan sesuai dengan SNI-01-4320-1996 tentang Syarat Mutu Minuman Tradisional, bahwa kadar abu yang dipersyaratkan maks. $1,5 \%$

3. Hasil Uji Waktu Larut

Tabel 5

Hasil Uji Waktu Larut

\begin{tabular}{cc}
\hline Formula & Waktu Larut \\
\hline X1 & 09.02 detik \\
\hline X2 & 11.13 detik \\
\hline X3 & 14.53 detik \\
\hline
\end{tabular}

Siregar (1992) menyebutkan bahwa syarat waktu yang diperlukan granul 
untuk melarut kurang dari 5 menit. Dapat disimpulkan bahwa pada ketiga formula memiliki waktu larut yang baik.

4. Hasil Uji Waktu Alir dan Sudut Diam

\section{Tabel 6}

Hasil Uji Waktu Alir

\begin{tabular}{ccccc}
\hline Formula & Waktu (Detik) & Diameter & Tinggi & Sudut Diam \\
\hline & & & & \\
& & $(\mathrm{cm})$ & $(\mathrm{cm})$ & $\left({ }^{\mathbf{o}}\right)$ \\
\hline $\mathrm{X} 1$ & 02.99 & 6,79 & 2 & 30,47 \\
\hline $\mathrm{X} 2$ & 03.80 & 6,28 & 2,17 & 34,43 \\
\hline $\mathrm{X} 3$ & 05.55 & 6,83 & 2,67 & 37,88 \\
\hline
\end{tabular}

(Anshory, Syukri, \& Malasari, 2007) menyebutkan bahwa persyaratan waktu alir yaitu tidak lebih dari 10 detik, maka serbuk instan tersebut memiliki waktu alir yang baik. Dapat disimpulkan bahwa pada ketiga formula memiliki waktu alir yang baik karena ketiganya memiliki waktu alir kurang dari 10 detik. Sedangkan sudut diam bertujuan untuk mengetahui sifat alir dari serbuk. (Voight, 1995) menyebutkan bahwa semakin datar kerucut yang dihasilkan maka sudut diamnya makin kecil artinya sifat alir semakin tidak baik. Pada formula 1 didapatkan rata - rata sudut diam sebesar $30,47^{\circ}$, formula 2 didapatkan rata - rata sudut diam sebesar $34,43^{\circ}$ dan formula 3 didapatkan rata - rata sudut diam sebesar $37,87^{\circ}$. Maka dapat disimpulkan bahwa ketiga formula serbuk instan perasan kulit buah jeruk nipis (Citrus aurantifolia) memiliki sudut diam yang baik. (Firjatullah, 2015) menyebutkan sudut diam yang baik antara $25-45^{\circ}$.

5. Hasil Uji Organoleptik

Tabel 7

Hasil Uji Organoleptik

\begin{tabular}{cccc}
\hline & \multicolumn{3}{c}{ Organoleptik } \\
\cline { 3 - 4 } Formula & & & \\
\cline { 3 - 4 } X1 & Aroma & Warna & Rasa \\
\hline & Khas & Putih & Asam \\
\hline jeruk & & manis \\
\hline nipis & & \\
\hline
\end{tabular}

Dari ketiga formula, hasil terbaik didapatkan pada formula 1 sedangkan yang kurang baik pada formula 3. Hal ini disebabkan karena beberapa faktor diantaranya yaitu pengaruh penambahan sukrosa dan pemberian konsentrasi maltodekstrin yang berbeda-beda. Pada warna dengan semakin banyak penambahan maltodekstrin maka warna yang dihasilkan akan semakin keruh, pada aroma dengan penambahan maltodekstrin tidak memberikan pengaruh yang signifikan karena aroma yang dihasilkan masih berupa aroma khas buah jeruk 
nipis dan pada rasa dengan penambahan maltodekstrin tidak memberikan pengaruh terhadap rasa serbuk instan perasan kulit buah jeruk nipis (Citrusaurantifolia), menurut (Jati, 2007) bahwa maltodekstrin tidak akan merubah rasa manis atau tanpa merubah produk semakin manis. Perbedaan rasa pada ketiga formula disebabkan karena perbedaan penambahan sukrosa dengan jumlah yang berbeda - beda, hal ini bergantung pada bobot hasil pengeringan yang dihasilkan. Semakin banyak bobot yang dihasilkan artinya penambahan sukrosa semakin sedikit dan menyebabkan rasa pada sediaan serbuk semakin asam sampai pahit.

6. Hasil Uji Hedonik Serbuk

\section{Tabel 8}

Rata-rata Hasil Uji Hedonik Serbuk Terhadap 10

Panelis

\begin{tabular}{cc}
\hline Formula & Nilai Rata - rata \\
\hline X1 & 4,5 \\
\hline X2 & 3,7 \\
\hline X2 & 3,2 \\
\hline
\end{tabular}

Berdasarkan nilai rata - rata yang diperoleh, hasil tertinggi terdapat pada formula 1 dengan nilai rata - rata 4,5 yang berarti suka sedangkan hasil terendah terdapat pada formula 3 dengan nilai rata - rata 3,2 yang berarti biasa saja. Artinya panelis lebih menyukai serbuk pada formula 1 dengan penambahan maltodekstrin $20 \%$.

7. Hasil Uji Stabilitas

Hasil pengamatan warna, aroma dan rasa dari ketiga formula ini memiliki hasil yang sama seperti awal meskipun sudah disimpan pada suhu suhu $0^{\circ} \mathrm{C}, 25^{\circ} \mathrm{C}$ dan $40^{\circ} \mathrm{C}$ selama 1 bulan. Pada formula 1 berwarna putih, aroma khas jeruk nipis, dan rasa asam manis, formula 2 berwarna putih, aroma khas jeruk nipis, dan rasa asam, sedangkan pada formula 3 berwarna putih gading, aroma khas jeruk nipis, dan rasa asam. Adapun hasil pengamatan kelembapan yang diuji dengan melakukan pengamatan dan perhitungan kadar air. Semakin besar kadar air yang dihasilkan makin lembab juga sediaan tersebut artinya semakin mudah untuk mikroba tumbuh didalam sediaan. Berdasarkan hasil pengamatan, pada ketiga formula memiliki kelembapan yang baik karena kadar air yang terkandung masih memenuhi persyaratan SNI SNI-01-4320-1996 yaitu kadar air maksimal adalah $3 \%$. Hasil uji stabilitas dapat dilihat pada: 
Tabel 9

Hasil Uji Stabilitas

\begin{tabular}{|c|c|c|c|c|c|c|c|}
\hline \multirow[b]{2}{*}{ Suhu } & \multirow[t]{2}{*}{ Sediaan } & \multirow{2}{*}{$\begin{array}{c}\text { Karakteristik } \\
\text { Pengujian } \\
\end{array}$} & \multicolumn{5}{|c|}{ Hari Ke- } \\
\hline & & & \multirow[b]{2}{*}{0} & \multirow[b]{2}{*}{7} & \multirow[b]{2}{*}{14} & \multirow[b]{2}{*}{21} & \multirow[b]{2}{*}{28} \\
\hline & & & & & & & \\
\hline & $\mathrm{X} 1$ & Warna & Putih & Putih & Putih & Putih & Putih \\
\hline & & Bentuk & Serbuk & Serbuk & Serbuk & Serbuk & Serbuk \\
\hline & & Aroma & Khas & Khas & Khas & Khas & Khas \\
\hline & & Rasa & Asam & Asam & Asam & Asam & Asam \\
\hline & & & manis & manis & manis & manis & manis \\
\hline & & Kelembapan & $0,98 \%$ & $1,15 \%$ & $1,29 \%$ & $1,23 \%$ & $0,88 \%$ \\
\hline & $\mathrm{X} 2$ & Warna & Putih & Putih & Putih & Putih & Putih \\
\hline & & Bentuk & Serbuk & Serbuk & Serbuk & Serbuk & Serbuk \\
\hline & & Aroma & Khas & Khas & Khas & Khas & Khas \\
\hline \multicolumn{8}{|l|}{$0^{\mathbf{o}}$} \\
\hline & & Rasa & Asam & Asam & Asam & Asam & Asam \\
\hline & & Kelembapan & $1,11 \%$ & $0,8 \%$ & $0,84 \%$ & $0,80 \%$ & $0,98 \%$ \\
\hline & X3 & Warna & Putih & Putih & Putih & Putih & Putih \\
\hline & & & gading & gading & gading & gading & gading \\
\hline & & Bentuk & Serbuk & Serbuk & Serbuk & Serbuk & Serbuk \\
\hline & & Aroma & Khas & Khas & Khas & Khas & Khas \\
\hline & & Rasa & Asam & Asam & Asam & Asam & Asam \\
\hline & & Kelembapan & $1,05 \%$ & $1,03 \%$ & $0,84 \%$ & $0,68 \%$ & $0,52 \%$ \\
\hline \multirow{5}{*}{\multicolumn{2}{|c|}{$\mathrm{X} 1$}} & Warna & Putih & Putih & Putih & Putih & Putih \\
\hline & & Bentuk & Serbuk & Serbuk & Serbuk & Serbuk & Serbuk \\
\hline & & Aroma & Khas & Khas & Khas & Khas & Khas \\
\hline & & & manis & manis & manis & manis & manis \\
\hline & & Kelembaban & $0,98 \%$ & $0,70 \%$ & $1,2 \%$ & $1,21 \%$ & $0,92 \%$ \\
\hline \multirow{5}{*}{\multicolumn{2}{|c|}{$\mathrm{X} 2$}} & Warna & Putih & Putih & Putih & Putih & Putih \\
\hline & & Bentuk & Serbuk & Serbuk & Serbuk & Serbuk & Serbuk \\
\hline & & Aroma & Khas & Khas & Khas & Khas & Khas \\
\hline & & Rasa & Asam & Asam & Asam & Asam & Asam \\
\hline & & Kelembaban & $1,11 \%$ & $0,80 \%$ & $1,27 \%$ & $1,03 \%$ & $0,96 \%$ \\
\hline \multirow{6}{*}{\multicolumn{2}{|c|}{$\mathrm{X} 3$}} & Warna & Putih & Putih & Putih & Putih & Putih \\
\hline & & & gading & gading & gading & gading & gading \\
\hline & & Bentuk & Serbuk & Serbuk & Serbuk & Serbuk & Serbuk \\
\hline & & Aroma & Khas & Khas & Khas & Khas & Khas \\
\hline & & Rasa & Asam & Asam & Asam & Asam & Asam \\
\hline & & Kelembaban & $1,05 \%$ & $0,72 \%$ & $1,11 \%$ & $0,90 \%$ & $0,78 \%$ \\
\hline \multirow{6}{*}{\multicolumn{2}{|c|}{$\mathrm{X} 1$}} & Warna & Putih & Putih & Putih & Putih & Putih \\
\hline & & Bentuk & Serbuk & Serbuk & Serbuk & Serbuk & Serbuk \\
\hline & & Aroma & Khas & Khas & Khas & Khas & Khas \\
\hline & & Rasa & Asam & Asam & Asam & Asam & Asam \\
\hline & & & manis & manis & manis & manis & manis \\
\hline & & Kelembaban & $0,98 \%$ & $0,79 \%$ & $0,20 \%$ & $0,26 \%$ & $0,26 \%$ \\
\hline
\end{tabular}


Uji Formulasi Dan Kemasan Serbuk Instan Perasan Kulit Buah Jeruk Nipis (Citrus Aurantifolia)

\begin{tabular}{ccccccc}
\hline & Warna & Putih & Putih & Putih & Putih & Putih \\
\hline & Bentuk & Serbuk & Serbuk & Serbuk & Serbuk & Serbuk \\
\hline Aroma & Khas & Khas & Khas & Khas & Khas \\
\hline Rasa & Asam & Asam & Asam & Asam & Asam \\
\hline & Kelembaban & $1,11 \%$ & $0,88 \%$ & $0,38 \%$ & $0,56 \%$ & $0,80 \%$ \\
\hline Warna & Putih & Putih & Putih & Putih & Putih \\
\hline & & gading & gading & gading & gading & gading \\
\hline & Bentuk & Serbuk & Serbuk & Serbuk & Serbuk & Serbuk \\
\hline Aroma & Khas & Khas & Khas & Khas & Khas \\
\hline Rasa & Asam & Asam & Asam & Asam & Asam \\
\hline & Kelembaban & $1,05 \%$ & $0,64 \%$ & $0,26 \%$ & $0,48 \%$ & $0,44 \%$ \\
\hline
\end{tabular}

8. Hasil Uji Hedonik Kemasan

Tabel 10

Rata Rata Hasil Uji

\begin{tabular}{cc}
\hline Kemasan & Nilai Rata - rata \\
\hline Alumunium Foil & 4 \\
\hline Plastik Klip & 3,3 \\
\hline
\end{tabular}

Berdasarkan penilaian dari 10 panelis untuk kemasan alumunium foil didapatkan nilai rata - rata yaitu 4 yang berarti suka, sedangkan untuk kemasan plastik klip diperoleh nilai rata - rata yaitu 3,3 yang berarti biasa saja.

\section{Kesimpulan}

Berdasarkan hasil penelitian Uji Formulasi dan Kemasan Serbuk Instan Perasan Kulit Buah Jeruk Nipis (Citrus aurantifolia) yang telah dilakukan dapat disimpulkan perasan kulit buah jeruk nipis (Citrus aurantifolia) dapat dijadikan sebagai serbuk instan. Serbuk instan perasan kulit buah jeruk nipis (Citrusaurantifolia) memenuhi evaluasi sediaan. Serbuk instan perasan kulit buah jeruk nipis (Citrusaurantifolia) memenuhi stabilitas sediaan. Kemasan alumunium foil adalah jenis kemasan yang disukai oleh panelis. 


\section{BIBLIOGRAFI}

Aliyah, Qonitah. (2019). Penggunaan Gum Arab Sebagai Bulking Agent Pada Pembuatan Minuman Serbuk Instan Labu Kuning Dengan Menggunakan Metode Foam Mat Drying. Edufortech, 4(2). Google Scholar

Anshory, H., Syukri, Y., \& Malasari, Y. (2007). Formulasi Tablet Effervescent Dari Ekstrak Ginseng Jawa (Tlinum Paniculatum) Dengan Variasi Kadar Pemanis Aspartam. Jurnal Ilmiah Farmasi, 4(1), 43-48. Google Scholar

Antari, Jilali, Chabaa, Samira, Iqdour, Radouane, Zeroual, Abdelouhab, \& Safi, Said. (2011). Identification Of Quadratic Systems Using Higher Order Cumulants And Neural Networks: Application To Model The Delay Of Video-Packets Transmission. Applied Soft Computing, 11(1), 1-10. Google Scholar

Budi. (2017). Tim Mitra Agro Sejati. CV. Pustaka Bengawan.

Budiana, N. S. (2013). Buah Ajaib Tumpas Penyakit. Penebar Swadaya Grup. Google Scholar

Farnsworth, N. R. (1996). Phytochemical Screening Of The Biologically Active Compounds From Higher Plants. Journal Pharmaceutical Sciences, 55, 227-276. Google Scholar

Firjatullah, Anis Amalia. (2015). Pengaruh Kadar Pvp K-30 Dalam Granul Manitol Terhadap Mutu Fisik Tablet Hisap Ekstrak Lidah Buaya (Aloe Vera) Program. University Of Muhammadiyah Malang. Google Scholar

Jati, Galih Prasetyo. (2007). Kajian Teknoekonomi Agroindustri Maltodekstrin Di Kabupaten Bogor. Google Scholar

Kristanti, Alfinda Novi. (2008). Buku Ajar Fitokimia. University Airlangga Press. Surabaya. Google Scholar

Kumalaningsih, Sri. (2014). Pohon Industri Potensial. Universitas Brawijaya Press. Google Scholar

Kumoro, Andri Cahyo. (2015). Teknologi Ekstraksi Senyawa Bahan Aktif Dari Tanaman Obat. Yogyakarta: Plantaxia. Google Scholar

Mpapa, Bahidin Laode. (2019). Kopi Saluan:: Local Coffe Khas Banggai. Deepublish. Google Scholar

Rahmawati, Fitri. (2013). Pengemasan Dan Pelabelan. Materi Pelatihan Kewirausahaan Bagi Kelompok Uppks. Google Scholar

Voight, R. (1995). Buku Pelajaran Teknologi Farmasi (Terjemahan). Universitas Gadjah Mada: Yogyakarta. Google Scholar 
Uji Formulasi Dan Kemasan Serbuk Instan Perasan Kulit Buah Jeruk Nipis (Citrus Aurantifolia)

\section{Copyright holder:}

Ahmad Azrul Zuniarto, Ahmad Mundzir, Nur Afifah Maulida (2021)

First publication right:

Syntax Literate: Jurnal Ilmiah Indonesia

This article is licensed under:

(c) (i) (?) 